\title{
INTERNATIONALIZATION SPEED AND BRAZILIAN COMPANIES PERFORMANCE
}

\author{
Submission: 03/10/2017 \\ Accept: 22/12/2018 \\ Dermeval Martins Borges Júnior ${ }^{1}$ \\ João Gonçalves Silva Muntaser² \\ Vinícius Silva Pereira ${ }^{3}$ \\ Catarine Palmieri Pitangui Tizziotti ${ }^{4}$ \\ Cláudio Francisco Rezende ${ }^{5}$
}

\begin{abstract}
The companies' performance that internationalize incurs in alterations along the internationalization process. Besides, this process might happen incrementally with time, slowly, or it can occur quickly, like in companies born global. Face the internationalization influence on companies' performance and how fast this process occurs, the aim of this paper is to examine the relation between internationalization speed and Brazilian public companies performance, which are part of this paper sample, except by the financial ones, listed on Brazilian multinational ranking by Dom Cabral Foundation (FDC), within the years 2007 to 2014. The data was collected from Economatica database and FDC reports, and analyzed through models of linear regression with panel data, considering two measures for internationalization speed. The results pointed no significant statically relation on the measure of internationalization speed and those companies' performance. This paper contributes to the literature by providing evidence regarding the effect of speed of internationalization on performance of Brazilian firms, since it is still little explored when compared to studies about the degree of internationalization and performance. For further researches, the use of others internationalization speed and performance variables are suggested.
\end{abstract}

Keywords: internationalization speed; performance; Brazilian multinational companies.

\footnotetext{
1 Universidade Federal de Uberlândia (UFU). Uberlândia, Minas Gerais, Brazil. He is a doctorate degree student of accounting at Universidade Federal de Uberlândia (UFU). E-mail: dermevalj14@ @ufu.br. ORCID: https://orcid.org/0000-0003-2279-449X

2 Universidade Federal de Uberlândia (UFU). Uberlândia, Minas Gerais, Brazil. He is a professor at Universidade Federal de Uberlândia (UFU). E-mail: joao.gsm@hotmail.com. ORCID:https://orcid.org/0000-0002-3877 5288

3 Universidade Federal de Uberlândia (UFU). Uberlândia, Minas Gerais, Brazil. Full time professor at Universidade Federal de Uberlândia (UFU). He has doctorate in business administration from FGV-EAESP. E-mail: viniciuss56@ufu.br. ORCID: https://orcid.org/0000-0002-4521-9343 4 Universidade Federal de Uberlândia (UFU). Uberlândia, Minas Gerais, Brazil. Full time professor at Universidade Federal de Uberlândia (UFU). She has doctorate in production engineering from Universidade Federal de São Carlos (UFSCAR). E-mail: catarinepitangui@ufu.br ORCID: https://orcid.org/0000-0002-2892-0197

5 Universidade Federal de Uberlândia (UFU). Uberlândia, Minas Gerais, Brazil. He has master degree in business administration and undergraduate degree in economics from Universidade Federal de Uberlândia (UFU). E-mail: claudiochico1@hotmail.com ORCID: https://orcid.org/0000-0001-8709-3884
} 


\section{RESUMO}

O desempenho das empresas que se internacionalizam incorre em alterações no decorrer do processo de internacionalização. Além disso, esse processo pode acontecer de modo incremental ao longo do tempo, de forma lenta, ou pode ocorrer rapidamente, como no caso das empresas que já nascem globais. Diante da influência da internacionalização no desempenho das empresas e a velocidade com que o processo de internacionalização ocorre, este trabalho tem como objetivo examinar a relação entre velocidade de internacionalização e o desempenho das empresas abertas brasileiras, as quais compõem a amostra deste trabalho, exceto as financeiras, listadas no ranking das multinacionais brasileiras da Fundação Dom Cabral (FDC) no período de 2007 a 2014. Os dados foram coletados da base Economatica e relatórios da FDC, e analisados a partir de modelos de regressão linear com dados em painel, considerando duas medidas para a velocidade de internacionalização. Os resultados indicaram que não existe relação estatisticamente significativa entre as medidas de velocidade de internacionalização e o desempenho dessas empresas. Este estudo contribui para a literatura ao fornecer evidencias relativas ao efeito da velocidade de internacionalização no desempenho das firmas brasileiras, uma vez que esta ainda é pouco explorada quando comparada aos estudos sobre o grau de internacionalização. Para pesquisas futuras, sugere-se a utilização de outras variáveis de velocidade de internacionalização e de desempenho.

Palavras-chave: velocidade de internacionalização; desempenho; multinacionais brasileiras.

\section{INTRODUCTION}

The globalization process imposed a new market context to companies, where competition became global instead of local, that way, to keep the competitiveness it is needed to trespass geographic boundaries aiming to serve consumers around the world. Due to this situation, Larrinaga (2005) says that among the most relevant strategies there is the internationalization, which basically consists of the decision of operating in overseas markets, in an interesting way of growth and entrepreneur development.

In Brazil, it is visible the expansion growth of international acting organizations, as shown in the Ranking of Brazilian multinationals, made by Dom Cabral Foundation (2015) by indicating a 7\% growth of the internationalization indexes for 2014 compared to 2013 . Furthermore, as shown in the same report, $59.6 \%$ of the companies analyzed said to intend expand their situation overseas in the next years.

There are many studies connecting internationalization and the companies' performance, standing out among those studies, there is Grant (1987) which indicates the positive relation of internationalization and profitability of manufacturing companies in the United Kingdom (positive linear relationship); Daniels and Bracker (1989) verified the companies' performance growth by internationalization themselves until reaching an optimum point, only then it starts to decrease (inverted U-shaped); Lu and Beamish (2001) showed that in the early internationalization stages, performance tends to decrease due to susceptibility to the new and unknown, then grow according the knowledge development and the company capability (U-shaped).

According to the results heterogeneity in studies that relate internationalization and performance, Contractor, Kundu and Hsu (2003) proposed a three stages model: in the first, the company shows negative results due its early internationalization stage, facing entrance barriers; secondly, there is a performance improvement thanks to the company's maturation in the internationalization process, reaping the benefits of acting globally; in the last stage, there is a performance drop duo the company expands more than a level considered great.

In view of the above, it can be seen that the performance of companies that are internationalized changes during the internationalization process. For Johanson and Vahlne (1977) this process occurs incrementally over time, and therefore proceeds slowly. In contrast, more re- 
cent studies, such as those by Chetty and Campbell-Hunt (2004) and Knight and Cavusgil (1996), suggest that internationalization can occur rapidly by considering companies that are already born global. It is worth highlighting the work of Hilmersson and Johanson (2015), which presents relevant results regarding the impact of this issue of the speed of internationalization on the performance of Swedish small and medium enterprises.

Considering the different effects of the internationalization influence on the companies' performance and the speed which the internationalization process can occur, this paper seeks to answer the following question: what is the relation between internationalization speed and Brazilian internationalized companies' performance?

The study's main objective is to examine the relationship between the speed of internationalization and the performance of the Brazilian internationalized public companies. To achieve the general objective, the following specific objectives are enumerated: i) to raise secondary data necessary for the study; ii) to elaborate and apply the multiple linear regression models referring to the two internationalization speed dimensions described in Hilmersson and Johanson (2015); iii) to analyze and compare the results obtained.

The Brazilian internationalized public companies were those firms with capital control and management, mainly, from Brazil, with international operations (such as sales offices, distribution centers, manufacturing, franchising, service rendering et cetera), as stated in Fundação Dom Cabral (2015) reports, and with shares negotiated in Brazilian Stock Exchange. So, firms in early stages of internationalization that only operate abroad or export irregularly, were not considered in this study.

There is a lack of a clear definition about the concept of internationalization speed on literature. The usually meaning of the term refers to speed as the time to internationalization. Therefore, the most common measure for speed of internationalization is some international dimension (such as number of subsidiaries abroad, foreign sales, foreign market entry, degree of internationalization et cetera) divided by the number of years since the firms' international events or, simply, the firm age. (CHETTY; JOHANSON; MARTín, 2014).

Regarding firms performance, were employed two economic indexes obtained from financial data of sample firms. The first was return on assets (ROA), which indicates how profitable a firm is relative to its assets, this index was measured by the ratio between net income and total assets. The second was net margin, which indicates how profitable a firm is relative to its revenues, this index was measured by the ratio between net income and net revenues. (MATARAZZO, 2010)

According to Hilmersson and Johanson (2015), there are still few studies dealing with the speed of internationalization, especially as an independent variable. In Brazil, little is known of studies that consider the effects of speed on performance of internationalized companies. Said that, this study can contribute in two significant dimensions: i) fill an important gap with regard to the study of the internationalization strategy of Brazilian companies; ii) to make possible a contact between the effect of the internationalization strategy and the performance of the Brazilian public companies with small and medium Swedish companies studied by Hilmersson and Johanson (2015).

\section{THEORETICAL BACKGROUND}

\subsection{Internationalization of Companies}

By analyzing various internationalization concepts of companies in their studies, Larrinaga (2005) defines it as a corporate growth strategy by international geographical diversification, through a long-term evolutionary and dynamic process that gradually affects different 
activities of the value chain and the organizational structure of the company, with a commitment and increasing involvement of its resources and capabilities with the international environment, and based on an incremental knowledge.

Thus, the internationalization of companies can be considered as a process in which companies gradually increase their participation in the international market, that is, internationalization occurs through a series of incremental decisions, such as deciding on start exporting products, set up subsidiary abroad, and so on. That way, instead of making large investments scattered over time to access overseas markets, companies tend to develop their international operations in small steps. (JOHANSON; WIEDERSHEIM-PAUL, 1975; JOHANSON; VAHLNE, 1977).

These small steps are considered stages of the internationalization process. By studying four Swedish companies, Johanson and Wiedershem-Paul (1975) were able to clearly identify four stages of internationalization, although they presented different speeds according to each organization, which were: i) the company does not have regular exports; ii) exports are made through independent representatives; iii) sales through subsidiaries; iv) production made in other countries. From the work of Johanson and Wiedershem-Paul (1975), several other studies have suggested new configurations for the stages involved in the internationalization process, such as those of Bilkey and Tesar (1977), Cavusgil (1980) and Reid (1981).

According to Johanson and Vahlne (1977), this process of gradual internationalization, which passes through certain stages, is observed in companies in view of the various factors that suppress the adoption of strategies and other access tools to other countries, such as a lack of knowledge about foreign markets, risk aversion, uncertainties, large amount of resources needed, among other factors.

Despite this, other studies have shown limitations to the internationalization model through stages. One example describes how frailty of this model is that of companies that have already been launched to the international market, called Born Globals. With the new market conditions, where there is a growth of specialization and number of niche markets, some companies that produce certain types of products or very specific components have an instant need to access international markets, since domestic demand, by itself, would not be enough, or else the entrepreneurs of high technology markets who need to sell their innovative products to other countries. Likewise, there is a need for imported materials industries that are not obtained in their home country. Finally, whatever the reason, it is noticeable the breach of stages in the case of Born Globals. (MADSEN; SERVAIS, 1997).

In view of this dynamics of the internationalization process, it has become bigger the literature focuses on studies about different dimensions of the process, such as the speed which an organization internationalizes itself. The speed concept basically refers to the length of time between an occurrence of certain events, for example, the time it takes to start a business to its first international operation. This speed analysis represents one of the most important forms of understanding how the internationalization process develops. (CASILLAS; ACEDO, 2013).

According to Casillas and Acedo (2013), internationalization speed can be presented in different ways, but three are worth highlighting: i) speed of increasing intensity in the external market, such as the growth of sales proportion abroad over a specific period of time; ii) speed of increasing resources committed to foreign operations, measured to the proportion of the company's assets abroad in a time period; iii) speed of the expansion in international markets, such as the number, variety and distance of the countries in which the company is active. 


\subsection{Measures of Performance}

Traditional measures of performance are based on accounting data. They present advantages as being available in financial reports, or being easily calculated and interpreted. (PETERSON; PETERSON, 1996).

In this context, Boshoff and Mels (1995) suggest that the objective of measuring a company performance is associated with the invested resources maximization. Kassai et al. (2005) corroborate that traditional measures of performance consider it sufficient for the profit to cover the cost of third-party capital, that is, if the profit earned by a given company is considered acceptable once it is able to exceed the third-party capital expenditures.

In the design of Eiteman, Stonehill and Moffett (2002), traditional financial statements such as Balance Sheet and Income Statement provide much of the data for the analysis of financial companies' performance. Return on sales, return on investments/assets, return on shareholders' equity, net profit margin and EBITDA are some known and calculated valuations in different ways.

The economic-financial indicators are used to evaluate the companies' performance through information available in the financial statements. Among the indicators: liquidity indicators (current liquidity, dry liquidity, immediate liquidity and general liquidity); activity indicators (average storage period, average term of payment to suppliers, average collection period); indebtedness indicators of structure and third-party capital/equity ratio; third-party capital ratio/ total liability; immobilization of permanent resources (DALLABONA; BEUREN, 2015).

In addition to the above indicators, several measures are used to scale the financial companies' performance. Krauter (2006) highlights Return on Assets (ROA), Return on Equity (ROE), Return on Net Assets (RONA), Earnings per Share (EPS) and Price/Profit Index ). The Table 1 shows the description of how these measures are quantified.

Table 1 - Main finance performance measures

\begin{tabular}{|c|c|}
\hline Performance measure & Metering \\
\hline Return on Asset (ROA) & Ratio between net income and total assets. \\
\hline Return on Equity (ROE) & $\begin{array}{c}\text { Ratio between net income and shareholders' equi- } \\
\text { ty. }\end{array}$ \\
\hline Return on Net Assets (RONA) & $\begin{array}{c}\text { Ratio of net operating income after income tax } \\
\text { (NOPAT) to total net assets. }\end{array}$ \\
\hline Earnings per share (EPS) & $\begin{array}{c}\text { Relationship between net income and number of } \\
\text { company shares. }\end{array}$ \\
\hline Price/Profit Index (P/L) & $\begin{array}{c}\text { Ratio between the market price of the share and } \\
\text { the earnings per share. }\end{array}$ \\
\hline
\end{tabular}

Source: Own elaboration.

According to Damodaran (2004), after the separation of the funding effects and operational effects, ROA provides a clearer measure of the true return on these assets. The work of Andrade and Galina (2013) states that the assets return is an indicator that reflects company profitability in relation to its total assets, indicating how efficient management is in the use of its total assets.

Based on these assumptions, this study will use as a financial performance measures the Return on Assets (ROA), obtained by dividing net income over assets, and Net Margin (NM), calculated from dividing net income by liquid sales. 
Grant (1987), studying a group of UK manufacturing firms, noticed that internationalization was positively associated with higher returns over the 13-year period. On the other hand, by considering multinational companies from developing economies, Andrade and Galina (2013) found a negative linear relationship between the degree of internationalization and performance, so that, the higher the degree of internationalization the smaller the company performance tends to be.

In examining the internationalization strategy effects on Japanese small and medium-sized enterprises' performance, Lu and Beamish (2001) saw that exportation and direct investment abroad impact differently on corporate performance. The exports showed a negative linear relation with the performance, while the direct investments abroad presented a non-linear relation, so that the smaller the direct foreign investments the worse the performance and the bigger the investments the better the performance, that is to say, the relationship between internationalization and performance, in this specific case, indicated a U-shaped curve.

Mohr and Batsakis (2017) analyzed data from 110 international retailers over the period between 2003 to 2012 with the objective to test the effects of rapid internationalization on firm performance (measured by return on assets - ROA and net income to total equity-ROE). Among results, the authors observed a curvilinear association between internationalization speed and firm performance (inverted U-shaped), suggesting that positive effects of rapid internationalization give way to negative effects when internationalization speed increases. Additionally, the relationship showed be moderated by geographic scope and international experience of firms.

According to Daniels and Bracker (1989), the relationship between internationalization and performance has an inverted " $U$ " shape, better saying, the company performance increases as it accesses other foreign markets, however, this does not occur indefinitely. There is an optimum point, when achieved, causes any increases in internationalization to result in a drop in performance. Several reasons are presented to explain this effect, such as the relative economic growth of the different markets, the economic and political risks of certain markets, competitiveness increase of foreign companies, among others.

Consonantly to these arguments, the first hypothesis of this study is enumerated:

H1: The relationship between the speed in increasing the intensity in international trade and performance has an inverted U-shaped relationship.

This hypothesis is justified in view of the fact that the company's ability to assimilate new export experiences is determined by its previous experiences. Thus a company that slowly increases its share in international trade is in a position where its capabilities are developed based primarily on its experiences in the domestic market so those experiences become institutionalized. Thereby, these companies end up having difficulties adapting their export strategies to the international markets, because it is hard to modify routines and customs. For a company in which international market growth intensifies rapidly, its routines are developed based on business experiences abroad, facilitating the internationalization process and positively impacting performance until it reaches the optimum point. (HILMERSSON; JOHANSON, 2015).

Considering the distinct effects of internationalization on performance found in the literature, Contractor, Kundu and Hsu (2003) propose an internationalization model involving three stages that represents an S-shaped curve: in the first stage the company presents negative results, since it is at the beginning of its internationalization process, facing barriers of entry; In the 
second stage the performance rises, as the company matures in internationalization, obtaining benefits provided by its performance on a global scale; and in the third stage there is a drop in performance as the company expands beyond the level considered optimal.

Mohr et al. (2014) studied the relationship between multinational firms' home region concentration and performance, taking as moderating variables foreign entry timing, internationalization speed and international experience. After analyzing data from a sample of 128 firms, totalizing 1,023 firm/year observations, the results indicated that internationalization speed positively moderates the above-mentioned association. The authors argue that, for firms expanding within their home region, rapid internationalization allows economies of scale and scope as result of the lower liability of foreignness.

When analyzing the internationalization of companies by way of patrimonial entry, Hill and Jones (2009) concluded that multinationals commit a high level of their resources due to the direct creation of assets and the allocation of resources in the foreign market, which happens in a way less accentuated in the non-patrimonial method of entry, in this case, relations with the foreign market are based on contracts that do not imply a direct mobilization of resources.

In this context, Johanson and Vahlne (1977) corroborate that in the internationalization by the mode of patrimonial entry it is possible that, initially, this high level of investments leads to a fall in the companies' financial performance, more accentuated than by the non-patrimonial mode. Owning to the fact that in the early stages of internationalization patrimonial entry mode, there is a high investment in assets, which can generate more costs than profits, leading to a capital cost increase, and a more long-term return on investment than in the short term. However, as the company increases its internationalization, based on accumulated experience, these costs are being reduced and this can reverse the initial falling situation in the company financial performance, presenting a U-shaped behavior.

Thereby, when considering the research of Contractor, Kumar, and Kundu (2007) and exploring the insertion of the predominant entry mode in the strategy of Brazilian companies internationalization, it is observed in the early stages of internationalization companies tend to get a high investment with costs superior to the benefits and reduction of its performance. However, with increased internationalization, the benefits outweigh the costs and companies perform better.

In face of this, the second hypothesis of this study is:

H2: The relationship between the speed of committed resources in foreign market activities and the performance has a U-shaped relation.

This hypothesis is justified because companies that quickly allocate resources to overseas markets acquire a platform that allows them to develop relationships with different stakeholders in different markets, and may even set up subsidiaries for production or sales. Despite these advantages, if such investments are made quickly, then the costs of the company will also increase rapidly, without guarantees of sales growth, compromising their initial performance. (HILMERSSON; JOHANSON, 2015).

\section{METHODOLOGY}

According to Crotty (1998), in any social research process four basic elements should be considered, namely: i) methods, the techniques or procedures used to gather and analyze data; ii) methodology, the process underlying the choice and use of particular methods to the desired 
outcomes; iii) theoretical perspective, the philosophical stance informing the methodology and providing a context; and iv) epistemology, the theory of knowledge embedded in the theoretical perspective and methodology. In this sense, the epistemological view of this research is objectivism, which means that the studied objects are considered as meaningful entities, thus the theoretical perspective was positivism. Regarding methodology and methods, this study engaged in secondary data research and employed quantitative method of statistical analysis, which will be describe further in this section.

Burrell and Morgan (1979) proposed four paradigms that represent the possible views of reality in social science theories, which are functionalist, interpretive, radical structuralist and radical humanist. This study may be classified, according to these paradigms, as functionalist, since correspond to an approach that seeks to promote rational explanations for social issues in order to generate knowledge to be applied in a practical way. It is worth mentioning that functionalist paradigm represents the mainstream regarding the conduction of organizational studies.

In this paper, two models of linear regression and U-shape or inverted U-shape were elaborated to examine the effect of internationalization speed on company performance in order to consider two of the three dimensions of internationalization speed proposed in Hilmersson and Johanson (2015). The sample consisted of public Brazilian multinational companies indicated in the Dom Cabral Foundation (FDC) Multinational Ranking from 2007 to 2014, the choice of sample period was due information availability regarding FDC reports at the time of data collection. The data were collected from Economatica database and Dom Cabral Foundation Multinational Ranking reports. In addition, in order to avoid selection biases, all public Brazilian firms with available data for at least one year were also selected, except for the financial ones due to their accounting specificities, totalizing 740 firms.

The independent variables based on the work of Hilmersson and Johanson (2015) were: i) the speed of increasing the intensity in the foreign market, measured by the annual percentage variation of the ratio between exports and total sales; ii) the speed of increasing committed resources to activities abroad, measured by the annual percentage variation of the ratio between the company's assets held abroad and its total assets.

To represent performance, were determined as dependent variables: i) the return on total assets, a measure used in Hilmersson and Johanson (2015) internationalization work; ii) the net margin of the companies studied, because is a usual measure used in Brazilian studies that relate performance and internationalization, such as Barcellos (2010) and Andrade and Galina (2013).

Control variables were used, such as: i) the size of the company, measured by the natural logarithm of net revenue; ii) the age of the company; iii) the company growth opportunity, measured by adding the market value of shareholders' equity to the total liabilities divided by the asset; iv) the company sector, to control effects in the case of manufacturing companies or services. The Table 2 presents the characterization of the variables used. 
Table 2 - Variables considered in the study

\begin{tabular}{|c|c|c|c|c|}
\hline Variable & Initials & Description & Definition & Source \\
\hline $\begin{array}{c}\text { Return on total as- } \\
\text { sets }\end{array}$ & RAT & Net Income on Total Assets & Dependent & Economatica \\
\hline $\begin{array}{c}\text { Speed on increasing } \\
\text { intensity in the fo- } \\
\text { reign market }\end{array}$ & SPDIN & $\begin{array}{c}\text { Ratio between net income and } \\
\text { net sales }\end{array}$ & Dependent & Economatica \\
\hline $\begin{array}{c}\text { Speed in increasing } \\
\text { resources with acti- } \\
\text { vities abroad }\end{array}$ & SPDRE & $\begin{array}{c}\text { Annual variation of the ratio } \\
\text { between the company's assets } \\
\text { held abroad and its total assets. }\end{array}$ & Independent & FDC \\
\hline Size & SIZE & $\begin{array}{c}\text { Measured through the natural } \\
\text { log of revenue }\end{array}$ & Control & Economatica \\
\hline Age & AGE & $\begin{array}{c}\text { Age from the date of listing on } \\
\text { the stock exchange until now }\end{array}$ & Control & Economatica \\
\hline $\begin{array}{c}\text { Growth Opportunity } \\
\text { Sector }\end{array}$ & GECTOR & $\begin{array}{c}\text { Sum of market value of net } \\
\text { equity with total liabilities divi- } \\
\text { ded by assets }\end{array}$ & Control & Economatica \\
\hline on the company's sector & Control & Economatica \\
\hline
\end{tabular}

Source: Own elaboration

The correlation analysis was the chosen method to verify the association between variables, which according to Lira (2004) is widely used to study the association degree between the variables. Stata software was used for statistical regression analysis to enable statistical calculations. The regression equations that verified the influence of the speed of internationalization on the companies' performance are given below.

Equation 1 seeks to verify the linear relationship between the independent variables and the return on total assets.

$$
R A T_{i t}=\alpha_{1}+\beta_{1} S P D I N_{i t}+\beta_{2} S P D R E i t+\beta_{3} S I Z E_{i t}+\beta_{4} A G E i t+\beta_{5} G O_{i t}+\beta_{6} S E C T O R+\varepsilon_{i t}
$$

Equation 2 seeks to verify the U-shape or inverted U-shape relationship between the independent variables and the return on total assets:

$$
\begin{aligned}
& R A T_{i t}=\alpha_{1}+\beta_{1} S P D I N i t+\beta_{2} S P D I N^{2} i t+\beta_{3} S P D R E i t+\beta_{4} S P D R E^{2} i t+\beta_{5} S I Z E t+\beta_{6} A G E i t+\beta_{7} G O i t \\
& \beta_{8} S E C T O R+\varepsilon_{i t}
\end{aligned}
$$

Equation 3 seeks to verify the linear relationship between the independent variables and the return on the net margin:

$$
N M_{i t}=\alpha_{1}+\beta_{1} S P D I N i t+\beta_{2} S P D R E i t+\beta_{3} \text { SIZEit }+\beta_{4} A G E i t+\beta_{5} \text { GOit }+\beta_{6} S E C T O R+\varepsilon_{i t}
$$

Finally, Equation 4 will verify the U-shape or inverted U-shape relationship between the independent variables and the net margin.

$$
\begin{aligned}
& N M_{i t}=\alpha_{1}+\beta_{1} S P D I N i t+\beta_{2} S P D I N^{2} i t+\beta_{3} S P D R E i t+\beta_{4} S P D R E^{2} i t+\beta_{5} S I Z E i t+\beta_{6} \text { AGEit }+ \\
& \beta_{7} \text { GOit }+\beta_{8} \text { SECTOR }+\varepsilon_{i t}
\end{aligned}
$$


The variables were winsonrized with the treating the outliers intention. In order to identify autocorrelation and multicollinearity problems, the Pearson correlation test and the Variance Inflation Factor (VIF) test were performed. To determine the best regression model to be used, Chow's, Breusch-Pagan's, and Hausman's tests were performed. The Chow test verifies the hypothesis that the variance of the cross-sectional units is equal to zero. The Breusch-Pagan test, from the F statistic, verifies that the residuals are independent and normally distributed. The latter, the Hausman test, allows a comparison between the fixed and random effects estimators. Finally, Woodridge tests were performed to verify autocorrelation and Wald test to verify heteroscedasticity.

\section{RESULTS AND DISCUSSION}

The data analysis and the research results start with Table 3, which presents the amounts of observations, averages, standard deviations, minimum and maximum of the variables considered in the study, except for the control dummy referring to the sector of activity of the companies, in order to enable the previous description of the data.

Table 3 - Descriptive Statistics

\begin{tabular}{cccccc}
\hline Variable & Observations & Avegare & $\begin{array}{c}\text { Standard Devia- } \\
\text { tion }\end{array}$ & Minimum & Maximum \\
\hline RAT & 3195 & 0.01125 & 0.08570 & -0.16156 & 0.11810 \\
NM & 2762 & 0.04688 & 0.13349 & -0.19838 & 0.24648 \\
SPDIN & 299 & -0.00454 & 0.38192 & -0.59494 & 0.74167 \\
SPDRE & 81 & 0.15692 & 0.58600 & -0.61225 & 1.4 \\
SIZE & 2759 & 20.60313 & 2.03859 & 15.90845 & 23.82907 \\
AGE & 4552 & 15.01011 & 8.49333 & 0 & 28 \\
GO & 2346 & 1.53060 & 0.71819 & 0.81289 & 3.09055 \\
\hline
\end{tabular}

Notes: (RAT) return on total assets, (NM) net margin, (SPDIN) speed in increasing intensity in foreign market, (SPDRE) speed of increasing committed resources to abroad activities, (SIZE) size, (GO) growth opportunity.

Source: Own elaboration

As observed in Table 3, companies considered in the sample indicated heterogeneity in their performance over the period studied, ranging from $-16.16 \%$ to $11.81 \%$ when measured by the return on assets (RAT) and $-19,84 \%$ to $24.65 \%$ when considering sales over net income (NM). Hilmersson and Johanson (2015) also found similar discrepancies in the performance of Swedish SMEs in studying the speed of internationalization. However, these authors found an average performance of approximately $10.34 \%$, that is, significantly higher than Brazilian public companies, from $1.13 \%$ to RAT and $4.7 \%$ to NM.

Another interesting heterogeneity refers to the two speed dimensions. In the case of speed in increasing the intensity in the foreign market (SPDIN), the minimum was $-59.49 \%$ and the maximum $74.17 \%$. Regarding the speed in the increase of the resources committed with the exterior activities (SPDRE), the minimum was $-61.23 \%$ and the maximum $140 \%$. Although Hilmersson and Johanson (2015) found similar discrepancies in Swedish micro and small firms, the results of their work indicated average SPDIN of approximately $2 \%$ and average SPDRE of $0 \%$, therefore, different from the observed speed averages here, $0.45 \%$ for SPDIN and $15.69 \%$ for SPDRE. It can be inferred that, on average, small and medium-sized Swedish companies internationalize faster by increasing the proportion between exports and total sales, while Brazilian public companies, on average, internationalize when they commit resources abroad, for example, with operations or facilities of subsidiaries in other countries. 
Regarding the ages of the companies studied (AGE), the average age was approximately 15 years, indicating that the sample of this work is made up of new organizations since Hilmersson and Johanson (2015) showed that an average company age is 43 years. Despite this, Brazilian public companies presented a growth opportunity (GO) substantially higher than the small and medium-sized Swedish companies of their study, $153 \%$ and $4.8 \%$, respectively. It is worth mentioning that the size of the companies (SIZE) does not allow comparison between both studies, considering the substantial difference in the way this variable was measured.

Still about the descriptive statistics, Table 4 shows the correlation matrix of the numerical variables considered in the study.

Table 4 - Correlation Matrix

\begin{tabular}{|c|c|c|c|c|c|c|c|}
\hline Variables & RAT & NM & SPDIN & SPDRE & SIZE & AGE & GO \\
\hline RAT & 1.00 & & & & & & \\
\hline NM & $0.86^{*}$ & 1.00 & & & & & \\
\hline SPDIN & 0.01 & 0.00 & 1.00 & & & & \\
\hline SPDRE & 0.07 & 0.05 & 0.19 & 1.00 & & & \\
\hline SIZE & $0.34^{*}$ & $0.26^{*}$ & 0.03 & 0.01 & 1.00 & & \\
\hline AGE & $-0.07^{*}$ & $-0.11^{*}$ & 0.01 & -0.06 & $-0.14^{*}$ & 1.00 & \\
\hline GO & -0.03 & $0.04^{*}$ & -0.07 & -0.03 & $-0.13^{*}$ & $-0.07^{*}$ & 1.00 \\
\hline
\end{tabular}

Notes: (RAT) return on total assets, (NM) net margin, (SPDIN) speed in increasing intensity in foreign market, (SPDRE) speed of increase in committed resources abroad, (SIZE) size, (GO) growth opportunity, (SECTOR) sector of the company, $\left({ }^{*}\right)$ statistically significant at the level of 0.10 .

Source: Own elaboration

According Table 4 it is shown the independent variables have low correlations between each other (below 0.2 ), thus representing a satisfactory indicator of low regressors endogeneity and autocorrelation. The company size variable (SIZE) was positively associated with measures of return on assets (RAT) and net margin (NM), with coefficients of 0.34 and 0.26 , respectively. This suggests that the company size and performance are correlated with each other, but with weak correlation. In contrast, the company age variable (AGE) was negatively associated with the performance measures, but with a negligible correlation, with coefficients of -0.07 and -0.11 for RAT and NM, respectively.

In order to increase consistency to the results achieved so far, we have Table 5, which from the equations 1,2,3 and 4 detailed in the methodology of this work, presents the coefficients through regressions. 
Table 5 - Regressions

\begin{tabular}{|c|c|c|c|c|}
\hline \multirow{2}{*}{ Model's Variables } & Model 1 & & Model 2 & NM \\
\cline { 2 - 5 } & RAT & RAT & NM & $0.701599^{* *}$ \\
\hline Constant & -0.1452 & -0.1464 & $0.710382^{* *}$ & -0.0227 \\
\hline SPDIN & 0.0038 & 0.0022 & -0.0172 & 0.0222 \\
\hline SPDRE & 0.0148 & 0.0162 & 0.01920 & $0.0264^{*}$ \\
\hline SIZE & 0.0057 & 0.0062 & $0.0268^{*}$ & 0.0018 \\
\hline AGE & -0.0021 & -0.0021 & 0.0018 & 0.0288 \\
\hline GO & 0.0544 & 0.0540 & 0.0299 & $0.0073^{*}$ \\
\hline SECTOR & 0.0000 & 0.0000 & $0.0072^{* *}$ & 0.0000 \\
\hline SPDIN & & -0.0001 & & 0.0000 \\
\hline SPDRE & & 0.0000 & & 0.0141 \\
\hline Breusch and Pagan & 0.0100 & 0.0106 & 0.0146 & 0.0100 \\
\hline Chow & 0.0000 & 0.0000 & 0.0100 & 0.0887 \\
\hline$R^{2}$ & 0.1925 & 0.1963 & 0.0841 & 3.10 \\
\hline Max. VIF & 1.17 & 3.10 & 1.17 & 0.6765 \\
\hline Wooldridge & 0.6520 & 0.7308 & 0.8384 & 0.0000 \\
\hline Wald & 0.0000 & 0.0000 & 0.0000 & \\
\hline
\end{tabular}

Notes: (RAT) return on total assets; (NM) net margin; (SPDIN) speed in increasing intensity in foreign market; (SPDRE) speed of increased resources committed abroad; (SIZE) size; $\left({ }^{*}\right)$ Statistically significant at the $1 \%$ level; $\left({ }^{* *}\right)$ statistically significant at the 5\% level; (Max. VIF) maximum Variance Inflation Factor observed, VIF values showed no multicollinearity; (Wooldridge) Wooldridge test for autocorrelation in panel data, the test showed no first order autocorrelation among variables. (Wald) Wald test for groupwise heteroskedasticity, the test showed heteroskedasticity among variables, because of this, the models were estimated using robust estimator of variance.

Source: Own elaboration

According to Models 1 and 2 shown in Table 5, it can be seen that the return on the total assets (RAT) and the net margin (NM) of the companies does not present a statistically significant relationship with the independent variables of the study. That is, there was no relationship between performance and speed in increasing the intensity in the foreign market, nor with the speed of the increase of resources committed with activities abroad.

These results do not confirm the Hypotheses $\mathrm{H} 1$ and $\mathrm{H} 2$, which suggest that the relationship between the speed in increasing the intensity in the international market and the performance has a relation in the inverted U-shaped form and that the relation between the speed in the increase of resources committed with activities abroad and performance has a U-shaped relationship, respectively, according to the study by Hilmersson and Johanson (2015).

It is suggested that the non confirmation of the research hypotheses, as well as the differences between the present study and the results found in the work of Hilmersson and Johanson (2015) are justified by the existence of several other researches that attest the relationship between the degree of internationalization and the performance (Grant, 1987; Daniels and Bracker, 1989; Johanson and Vahlne, 1977; Lu and Beamish, 2001; Contractor, Kundu and Hsu, 2003; Contractor, Kumar and Kundu, 2007; Hill and Jones, 2009; Andrade and Galina, 2013), however there is not the same range of studies that seek to relate the speed with which companies internationalize with their performance. That is, it is possible that the degree of internationalization achieved by companies is more influential in their performance than the speed with which they can internationalize. 
Additionally, the observed results may be a consequence of the firms market context, since Brazilian domestic market is very ample, thus representing a more simple and less costly alternative strategy than internationalization. Even firms seeking international expansion may face difficulties due constraints and institutional factors at Brazil country level. In this sense, the effect of internationalization speed on companies' performance, although evidenced in the literature, were not significant when considering Brazilian firms.

It is worth notice that the results of Table 5 point to a statistically significant positive relation between the control variable size (SIZE) and the net margin (NM), according to the second regression of Model 2. Influence of this fact is an increase of $1 \%$ in the variation of the size of the company leads to an increase of $0.0264 \%$ of the net margin. This result did not find a coincidence with the study by Hilmersson and Johanson (2015), who concluded that there was no relation between the size and the performance of the companies.

\section{CONCLUSION}

The present study had as main objective to examine the effect of the internationalization speed on the Brazilian's internationalized public companies' performance. Were determined as dependent variables to represent performance, return on total assets, measure used in the work on internationalization speed of Hilmersson and Johanson (2015) and the net margin, because is a usual measure used in Brazilian studies that relate performance and internationalization, such as Barcellos (2010) and Andrade and Galina (2013).

The results did not confirm the hypotheses $\mathrm{H} 1$ and $\mathrm{H} 2$, which suggest that the relationship between the speed in increasing the intensity in the international market and the performance has a relation in inverted $U$-shaped form and that the relation between the speed in the increase of committed resources with abroad activities and performance has a U-shaped relationship, respectively. Even so, this study contributes to the literature about the subject by providing evidence regarding the effect of speed of internationalization on performance of Brazilian firms, since speed of internationalization is still little explored when compared to studies about the relation between degree of internationalization and performance.

This study may also contribute to business practice by showing that firm's performance does not appear to be influenced by speed of internationalization process, so managers interested in increasing measures of return on assets and net margin should not boost internationalization process as strategy for this. For education purposes, this paper provides further insights to be discussed in classes, especially in disciplines about business strategy, since it presents a new approach to firms' internationalization, showing that there are elements beyond simply the degree of internationalization, such as the speed at which this process occurs.

In order to continue this theme and seek to explain whether or not there is a relation between the internationalization speed and performance, and to further enrich this previously unexplored context, it is recommended that in future research, other variables of internationalization speed be tested, such as the international markets expansion speed. Besides that, it is also suggested others performance variables utilization, as the return on equity and earnings per share. Finally, the relation between speed of internationalization and performance should be tested considering moderating variables. 


\section{REFERENCES}

ANDRADE, A. M. F.; GALINA, S. V. R. Efeitos da internacionalização sobre o desempenho de multinacionais de economias em desenvolvimento. Revista de Administração Contemporânea, v. 17. n. 2, p. 238-286, 2013.

BARCELLOS, E. P. Internacionalização de empresas brasileiras: um estudo sobre a relação entre grau de internacionalização e desempenho financeiro. 2010. Tese (Doutorado). Faculdade de Economia, Administração e Contabilidade, Universidade de São Paulo, São Paulo, 2010.

BILKEY, W. J.; TESAR, G. The export behavior of smaller Wisconsin manufacturing firms. Journal of International Business Studies, v. 8, n. 1, p. 93-98, 1977.

BOSHOFF, C.; MELS, G. A causal model to evaluate the relationships among supervision, role stress, organizational commitment and internal service quality. European Journal of Marketing, v. 29, n. 2, p. 23-42, 1995.

BOTELHO, D.; TOSTES, F. D. Modelagem de Probabilidade de Churn. Revista de Administração de Empresas, v. 50, n. 4, p. 396-410, 2010.

BURRELL, G.; MORGAN, G. Sociological Paradigms and Organisational Analysis: Elements of the Sociology of Corporate Life. Burlington: Ashgate, 1979.

CASILLAS, J. C.; ACEDO, F. J. Speed in the internationalization process of the firm. International Journal of Management Reviews, v. 15, n. 1, p. 15-29, 2013.

CAVUSGIL, S. T. On the internationalization process of firms. European Research, v. 8, n. 6, p. 273-281, 1980.

CHETTY, S.; CAMPBELL-HUNT, C. A. A strategic approach to internationalization: a traditional versus a born global approach. Journal of International Marketing, v. 12, n. 1, p. 57-81, 2004.

CHETTY, S.; JOHANSON, M.; MARTÍN, O. M. Speed of internationalization: Conceptualization, measurement and validation. Journal of World Business, v. 49, n. 4, p. 633-650, 2014.

CONTRACTOR, F. J.; KUMAR, V.; KUNDU, S. K. Nature of the relationship between international expansion and performance: The case of emerging market firms. Journal of World Business, v. 42, n. 4, p. 401-417, 2007.

CONTRACTOR, F. J.; KUNDU, S. K.; HSU, C. A three-stage theory of international expansion: The link between multinationality and performance in the service sector. Journal of International Business Studies, v. 34, n. 1, p. 5-18, 2003.

CROTTY, M. The foundations of social research: meaning and perspective in the research process. Crows Nest: Allen \& Unwin, 1998.

DALLABONA, L. F.; BEURAN, I. M. Relação da folga organizacional com medidas de desempenho de empresas brasileiras. Revista Pretexto, v. 16, n. 2, p. 31-49, 2015.

DAMODARAN, A. Finanças corporativas: teoria e prática. Porto Alegre: Bookman, 2004. 
DANIELS, J. D.; BRACKER, J. Profit performance: do foreign operations make a difference?. Management International Review, v. 29, n. 1, p. 46-56, 1989.

EITEMAN, D.; STONEHILL, A. K.; MOFFETT, M. H. Administração Financeira Internacional. Porto Alegre: Bookman, 2002.

FUNDAÇÃO DOM CABRAL. Ranking FDC das Multinacionais Brasileiras 2015. São Paulo: Fundação Dom Cabral, 2015.

GRANT, R. M. Multinationality and performance among British manufacturing companies. Journal of International Business Studies, v. 18, n. 3, p. 79-89, 1987.

HILL, C.; JONES, G. Foreign Direct Investment, Analysis of Aggregate Flows. Mason: South Western Cengage Learning, 2009.

HILMERSSON, M.; JOHANSON, M. Speed of SME Internationalization and Performance. Management International Review, v. 56, n. 1, p. 67-94, 2015.

JOHANSON, J.; VAHLNE, J. E. The internationalization process of the firm - a model of knowledge development and increasing foreign market commitments. Journal of Internationalization Business Studies, v. 8, n. 1, p. 23-32, 1977.

JOHANSON, J.; WIEDERSHEIM-PAUL, F. The internationalization of the firm - four Swedish cases. Journal of Management Studies, v. 12, n. 3, p. 305-322, 1975.

KASSAI, J. R.; CASANOVA, S.; DOS SANTOS, A.; ASSAF NETO, A. Retorno de investimento: abordagem matemática e contábil do lucro empresarial. São Paulo: Atlas, 2005.

KNIGHT, G. A.; CAVUSGIL, S. T. The born global firm: A challenge to traditional internationalization theory. Advances in international marketing, v. 8, n. 1, p. 11-26, 1996.

KRAUTER, E. Medidas de avaliação de desempenho financeiro e criação de valor: um estudo com empresas industriais. In: Simpósio de Excelência em Gestão e Tecnologia, 2006, Resende. Anais... Resende: Associação Educacional Dom Bosco, 2006.

LARRINAGA, O. V. The Internationalization of the Firm and Multinational Enterprise: a Contemporacy Conceptual Review. Cuadernos de Gestión, v. 5, n. 2, p. 55-73, 2005.

LIRA, S. A.. Análise de correlação: abordagem teórica e de construção dos coeficientes com aplicações. 2004. Dissertação (Mestrado em Ciências). Curso de Pós-graduação em Métodos Numéricos em Engenharia dos Setores de Ciências Exatas e de Tecnologia, Universidade Federal do Paraná, Curitiba, 2004.

LU, J. W.; BEAMISH, P. W. The internationalization and performance of SMEs. Strategic Managment Journal, v. 22, n. 7, p. 565-586, 2001.

MADSEN, T. K.; SERVAIS, P. The Internationalization of Born Globals: an Evolutionary Process? International Business Review, v. 6, n. 6, p. 561-583, 1997.

MATARAZZO, D. C. Análise financeira de balanços: abordagem gerencial. 7. ed. São Paulo: Atlas, 2010.

MOHR, A.; BATSAKIS, G. Internationalization Speed and Firm Performance: A Study of the Market- 
Seeking Expansion of Retail MNEs. Management International Review, v. 57, n. 2, p. 153 177, 2017.

MOHR, A.; FASTOSO, F.; WANG, C.; SHIRODKAR, V. Testing the Regional Performance of Multinational Enterprises in the Retail Sector: The Moderating Effects of Timing, Speed and Experience. British Journal of Management, v. 25, n. S1, p. 100-115, 2014.

PETERSON, P. P.; PETERSON, D. R. Performance de empresas e medidas de valor adicionado. Virginia: Fundação de Pesquisa do Instituto de Analistas Financeiros Certificados, 1996.

REID, S. D. The decision-maker and export entry and expansion. Journal of International Business Studies, v. 12, n. 1, p. 101-112, 1981.

\section{Contribution of authors}

Every author should account for at least one component of the work. Paper approved for publication need to specify the contribution of every single author.

\begin{tabular}{|c|c|c|c|c|c|}
\hline Contribution & [Author 1] & [Author 2] & [Author 3] & [Author 4] & Author 5] \\
\hline 1. Definition of research problem & $\mathrm{v}$ & $\mathrm{v}$ & $\mathrm{v}$ & & \\
\hline $\begin{array}{c}\text { 2. Development of hypotheses or research } \\
\text { questions (empirical studies) }\end{array}$ & $\mathrm{v}$ & $\mathrm{v}$ & $\mathrm{v}$ & & \\
\hline $\begin{array}{l}\text { 3. Development of theoretical propositions } \\
\text { (theoretical work) }\end{array}$ & $\mathrm{v}$ & $\mathrm{v}$ & $\mathrm{v}$ & & \\
\hline 4. Theoretical foundation / Literature review & $\mathrm{V}$ & $\mathrm{V}$ & & $\mathrm{V}$ & $\mathrm{V}$ \\
\hline 5. Definition of methodological procedures & $\mathrm{v}$ & $\mathrm{v}$ & $\mathrm{v}$ & & \\
\hline 6. Data collection & $\mathrm{V}$ & $\mathrm{V}$ & & & \\
\hline 7. Statistical analysis & $\mathrm{V}$ & $\sqrt{ }$ & & & \\
\hline 8. Analysis and interpretation of data & $\mathrm{V}$ & $\mathrm{V}$ & $\sqrt{ }$ & & \\
\hline 9. Critical revision of the manuscript & $\mathrm{V}$ & $\mathrm{V}$ & $\sqrt{ }$ & $\mathrm{V}$ & $\sqrt{ }$ \\
\hline 10. Manuscript writing & $\mathrm{v}$ & $\mathrm{v}$ & & & \\
\hline 11. Other (please specify) & & & & & \\
\hline
\end{tabular}

